\title{
ANALISIS PREFERENSI RUMAH TANGGA TERHADAP PRODUK JAMU SELAMA MASA PANDEMI COVID-19 DI RUMAH TANGGA, KELURAHAN BAKTIJAYA KECAMATAN SUKMAJAYA DEPOK
}

\section{ANALYSIS OF HOUSEHOLDS PREFERENCES TOWARD HERB PRODUCTS DURING THE COVID-19 PANDEMIC, IN BAKTIJAYA SUB-DISTRICT, SUKMAJAYA DISTRICT, DEPOK}

\author{
Asma Hasanah*, Trisna Insan Noor \\ Universitas Padjadjaran, Jl. Raya Bandung Sumedang KM. 21 \\ *E-mail: asmahsnh99@gmail.com \\ (Diterima 29-01-2021; Disetujui 03-06-2021)
}

\begin{abstract}
ABSTRAK
Corona Virus Disease 2019 (Covid-19) atau biasa disebut sebagai virus Corona merupakan wabah penyakit yang saat ini menjadi kekhawatiran di seluruh penjuru dunia, salah satunya adalah negara Indonesia. Covid-19 adalah penyakit yang berasal dari virus, saat virus masuk ke dalam tubuh akan dideteksi oleh sistem imun tubuh. Jika sistem imun tubuh yang dimiliki cukup kuat maka dengan sendirinya virus dapat dilawan oleh antibodi tubuh. Oleh sebab itu, cara yang tepat sembari menunggu antivirus adalah meningkatkan imunitas tubuh agar kemungkinan untuk terkena infeksi Covid-19 lebih kecil. Jamu merupakan salah satu obat-obatan tradisional yang dipercaya dapat meningkatkan imunitas tubuh. Jamu bagian dari obat tradisional yang sudah digunakan masyarakat Indonesia turun temurun sebagai pengobatan. Tujuan dari penelitian ini adalah untuk menganalisis kategori atribut yang menjadi preferensi rumah tangga terhadap produk jamu selama masa Pandemi Covid-19 di RT 09 dan 10 (Keluruhan Baktijaya, Kecamatan Sukmajaya RW 021) Kota Depok. Metode analisis yang digunakan dalam penelitian ini adalah Importance Performance Analysis (IPA), dan Customer Satisfication Index (CSI). Berdasarkan hasil IPA diperoleh preferensi rumah tangga terhadap produk jamu menunjukan bahwa kategori atribut paling penting dalam setiap atribut adalah jamu dalam bentuk cairan, khasiat jamu untuk menjaga kesehatan, harga jamu < 5.000 dan 5.000-10.000 rupiah, dan cita rasa jamu yang pahit. Berdasarkan hasil CSI diperoleh rumah tangga mayoritas merasa puas terhadap kinerja atribut produk jamu yang dikonsumsi.
\end{abstract}

Kata Kunci: Preferensi, Jamu, Pandemi Covid-19

\begin{abstract}
Corona Virus Disease 2019 (Covid-19) or commonly referred to as the Corona Virus is a disease outbreak that is currently a concern all over the world, one of which is Indonesia. Covid-19 is a disease that comes from a virus, when the virus enters the body it will be detected by the body's immune system. If the body's immune system is strong enough, the virus can be resisted by the body's antibodies by itself. Therefore, the right way while waiting for an antiviral is to increase the body's immunity so that the possibility of contracting Covid-19 infection is smaller. Jamu is a traditional medicine that is believed to increase the body's immunity. Jamu is part of traditional medicine that has been used by Indonesians for generations as a treatment. The purpose of this study was to analyze the category of attributes that became household preferences for herbal products during the Covid-19 Pandemic in RT 09 and 10 (Keluruhan Baktijaya, Kecamatan Sukmajaya RW 021) Depok City. The analytical methods used in this research are Importance Performance Analysis (IPA) and the Customer Satisfaction Index (CSI). Based on the results of $I P A$, it was obtained that household preferences for herbal products showed that the most important attribute categories in each attribute were herbal medicine in liquid form, the properties of herbal medicine to maintain health, the price of jamu $<5,000$ and 5,000-10,000 rupiah, and the
\end{abstract}


bitter taste of herbal medicine. Based on the CSI results, the majority of household were satisfied with the performance of the attributes of the medicinal products consumed.

Keywords: Preference, Jamu, Covid-19 Pandemic

\section{PENDAHULUAN}

Corona Virus Disease 2019 (Covid-19) biasa disebut virus Corona merupakan wabah penyakit yang menjadi masalah utama dunia sejak akhir tahun 2019, termasuk negara Indonesia. Covid19 merupakan penyakit yang berasal dari virus, pada umumnya ketika virus tersebut masuk ke dalam tubuh akan terjadi perlawanan oleh sistem imunitas tubuh. Sistem imunitas tubuh yang kuat akan menyebabkan virus dengan sendirinya dapat dilawan oleh antibodi tubuh.

Oleh karena itu, selama masa Pandemi Covid-19 masyarakat berusaha mencari cara untuk meningkatkan imunitas atau daya tahan tubuhnya. Salah satu cara yang dipercayai adalah dengan mengonsumsi jamu yang merupakan salah satu ramuan obat tradisional yang dipercaya dapat meningkatkan imunitas tubuh. Jamu di Indonesia sudah digunakan secara turun-temurun sebelum masuknya ilmu kedokteran modern.

Menurut Peraturan Menteri Kesehatan (Permenkes) Nomor 003/Menkes/Per/I/2010, definisi jamu adalah ramuan bahan yang terdiri atas bahan tumbuhan, hewan, mineral, dan sebagainya. Jamu sendiri memliki banyak jenis dan varian, manfaat yang dimiliki jamu berbeda-beda tergantung dari komposisi campurannya.

Preferensi rumah tangga terhadap setiap kategori atribut produk jamu akan menjadi hasil akhir yang menentukan jamu jenis dengan khasiat apa yang akan dibeli. Terbentuknya preferensi dipengaruhi oleh beberapa faktor-faktor seperti berikut (Shepherd dan Sparks, 1994):

1. Faktor Intrinsik, faktor seperti penampakan, aroma, suhu, kualitas, dan sebagainya.

2. Faktor Ekstrinsik, faktor seperti lingkungan, iklan produk, variasi waktu, dan musim.

3. Faktor Biologis, faktor seperti umur, jenis kelamin, dan aspek biologis.

4. Faktor Personal, faktor seperti tingkatan harapan, pengaruh dari orang lain, selera, emosi, dan persepsi.

5. Faktor Sosial Ekonomi, faktor seperti pendapatan keluarga, harga makanan, status sosial, dan keamanan, 
6. Faktor Pendidikan, faktor seperti pengetahuan individu dan keluarga, dan pengetahuan tentang gizi.

7. Faktor Kultur, faktor seperti agama, kepercayaan, dan tradisi daerah.

Preferensi dibentuk dari atributatribut yang melekat pada produk jamu dan dianggap paling penting oleh konsumen. Atribut produk adalah faktorfaktor yang menjadi pertimbangan konsumen dalam mengambil keputusan tentang pembelian suatu produk yang melekat pada produk itu sendiri (Simamora, 2004).

Atribut pada produk dibagi menjadi tiga hal, yaitu (Kotler, 2005):

1. Mutu Produk, menunjukan kemampuan sebuah produk untuk menjalankan fungsinya.

2. Ciri Produk, alat untuk membedakan produk perusahaan dengan pesaing.

3. Desain Produk, keunikan penampilan produk dengan tujuan menarik perhatian konsumen.

Kota Depok merupakan wilayah di Indonesia yang pertama kali terkena kasus positif Covid-19, dan sampai Desember 2020 termasuk ke dalam kategori wilayah zona merah atau wilayah dengan penyebaran virus yang tidak terkendali. Kecamatan Sukmajaya merupakan salah satu kecamatan di Kota
Depok dengan Rukun Warga (RW) zona merah terbanyak.

Fenonema tersebut menyebabkan jamu di Kota Depok menjadi salah satu pilihan untuk meningkatkan imunitas tubuh. Menurut pernyataan penjual jamu gendong di wilayah Cinere, Depok "permintaan jamu semakin meningkat, semenjak merebaknya virus Corona, yang tidak biasa meminum jamu beralih meminum jamu". Serta menurut pedagang rempah di Pasar Kemiri Muka, Depok, Adam (52 tahun) mengatakan bahwa bahan-bahan jamu mendadak diserbu banyak orang, dimana hal tersebut tidak pernah terjadi selama 32 tahun ia berdagang.

Oleh karena itu, penelitian ini dilakukan untuk melihat bagaimanakah preferensi rumah tangga terhadap produk jamu selama masa Pandemi Covid-19 di RT 09 dan 10 Kelurahan Baktijaya RW 021, Kecamatan Sukmajaya, Kota Depok dalam memilih setiap kategori atribut produk jamu yang nantinya membentuk preferensi mereka terhadap produk jamu.

\section{METODE PENELITIAN}

Penelitian dilaksanakan pada bulan Oktober-November 2020 di RT 09 dan 10 Kelurahan Baktijaya Kecamatan Sukmajaya RW 021 Kota Depok. Lokasi 
dipilih karena Kecamatan Sukmajaya termasuk kedalam salah satu kecamatan dengan RW zona merah terbanyak di Kota Depok.

Penelitian didesain secara kuantitatif dengan metode survey deskriptif. Data yang digunakan adalah data primer yang berasal dari pengisian kuesioner dan wawancara kepada responden dan penjual jamu di wilayah penelitian. Selain itu terdapat data sekunder yang bersumber dari berbagai lembaga atau instansi, buku, jurnal, skripsi, dan media informasi lainnya yang berhubungan dengan penelitian.

Responden dalam penelitian ini adalah anggota rumah tangga yang melakukan pembelian jamu di RT 09 dan 10 Kelurahan Baktijaya, Kecamatan Sukmajaya RW 21, Kota Depok. Teknik pengambilan sampel dilakukan dengan cara proportionate stratified random sampling. Populasi dalam penelitian yaitu rumah tangga RT 09 dan 10 di Kelurahan Baktijaya, Kecamatan Sukmajaya RW 21, Kota Depok yang berjumlah 105 KK. Peneliti menggunakan rumus slovin untuk menentukan jumlah responden. Berdasarkan rumus slovin tersebut dengan nilai kritis $10 \%$ maka didapati jumlah sampel yang diambil untuk dijadikan responden sebanyak 51 rumah tangga.

Teknik pengambilan sampel dengan proportionate stratified random sampling dilakukan karena keadaan populasi yang mempunyai unsur heterogen (Sugiyono, 2008). Dengan proportionate random sampling didapatkan pengambilan sampel untuk RT 09 sebanyak 34 rumah tangga, dan RT 10 sebanyak 17 rumah tangga.

Analisis data dalam penelitian ini menggunakan importance performance analysis (IPA) dan customer satisfication index (CSI) yang digunakan untuk menganalisis preferensi rumah tangga terhadap atribut-atribut jamu yang menjadi pertimbangan dalam membeli jamu.

\section{HASIL DAN PEMBAHASAN}

Kecamatan Sukmajaya merupakan salah satu kecamatan yang berada di Kota Depok Jawa Barat. Kecamatan Sukmajaya berlokasi di paling timur Kota Depok. Secara geografis Kecamatan Sukmajaya memiliki batas-batas wilayah sebagai berikut:
a. Utara : Kecamatan Cimanggis
b. Selatan : Kecamatan Cilodong
c. Barat : Kecamatan Pancoran Mas dan
Cipayung 
d. Timur : Kecamatan Tapos dan Cimanggis

Kecamatan Sukmajaya memiliki 11 kelurahan, yaitu Kelurahan Sukmajaya, Kelurahan Suka Maju, Kelurahan Mekarjaya, Kelurahan Abadi Jaya, Kelurahan Baktijaya, Kelurahan Cisalak, Kelurahan Kalibaru, Kelurahan Kalimulya, Kelurahan Kali Jaya, Kelurahan Cilodong, Kelurahan Jati Mulya, dan Kelurahan Tirta Jaya.

Kecamatan Sukmajaya memiliki luas wilayah sebesar $1.528,14$ ha atau $15,28 \mathrm{~km}^{2}$, dengan ketinggian wilayah dari permukaan laut $\pm 140 \mathrm{~m}$, kemiringan tanah 71,54 mengarah ke utara, sehingga keadaan tanah relatif datar. Kecamatan Sukmajaya sendiri apabila dilihat berdasarkan luas wilayahnya, lahannya paling banyak berfungsi sebagai lahan non pertanian dibandingkan lahan pertanian, sebesar 1.585 ha luas lahan mempunyai fungsi sebagai lahan non pertanian dan 10 ha luas lahan mempunyai fungsi sebagai lahan pertanian (non sawah).

Analisis Tingkat Kepentingan dan Kinerja (Importance Performance Analysis) Kategori Atribut Jamu

a. Menganalisis Posisi Atribut dalam Matriks IPA

\section{Metode Importance Performance} Analysis (IPA) dilakukan untuk mengetahui tingkat kepentingan dan kinerja atribut produk jamu apakah sudah sesuai antara realita dan harapan responden rumah tangga. Atribut-atribut tersebut adalah bentuk penyajian jamu, khasiat jamu, harga produk jamu, kandungan bahan jamu, dan cita rasa produk jamu.

Tabel 1. Kategori Atribut Bentuk Penyajian Jamu

\begin{tabular}{ccrr}
\hline No & $\begin{array}{c}\text { Kategori } \\
\text { Atribut }\end{array}$ & Importance & Performance \\
\hline 1 & Bubuk & 2,15 & 3,09 \\
2 & Tablet & 1,84 & 3,37 \\
3 & Cairan & 3,92 & 4,49 \\
\hline \multicolumn{2}{c}{ Jumlah } & $\mathbf{7 , 9 1}$ & $\mathbf{1 0 , 9 5}$ \\
\hline Rata-rata $(\overline{\bar{X}}, \overline{\boldsymbol{Y}})$ & $\mathbf{2 , 6 3}$ & $\mathbf{3 , 6 5}$ \\
\hline
\end{tabular}

Nilai rata-rata tingkat kepentingan 3 kategori atribut adalah 2,63 dan ratarata tingkat kinerja adalah 3,65. Kedua nilai ini yang menjadi garis tengah pada diagram Gambar 1.

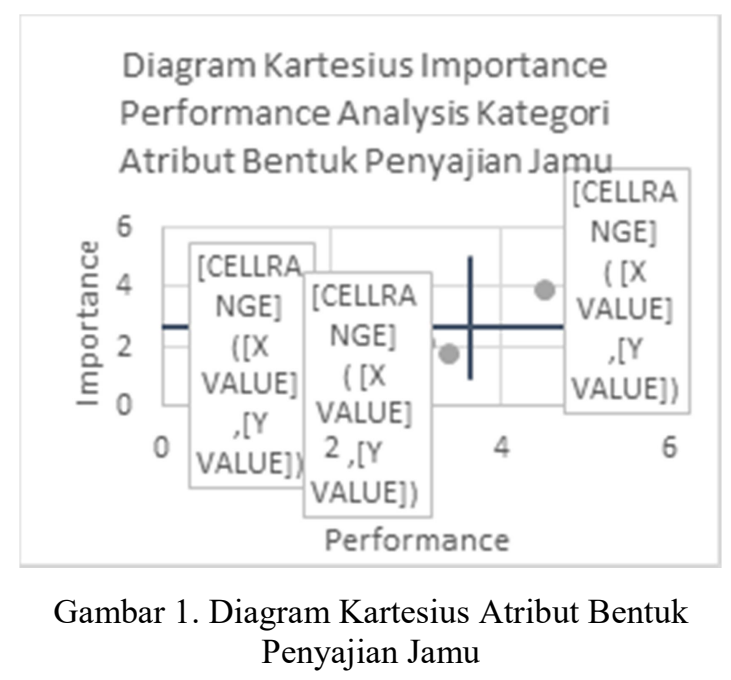


Tabel 2. Kategori Atribut Khasiat Jamu

\begin{tabular}{clrr}
\hline No & $\begin{array}{l}\text { Kategori } \\
\text { Atribut }\end{array}$ & Importance & Performance \\
\hline 1 & $\begin{array}{l}\text { Pengobatan } \\
\text { Penyakit }\end{array}$ & 3,62 & 3,64 \\
2 & $\begin{array}{l}\text { Perawatan } \\
\text { Tubuh }\end{array}$ & 3,13 & 3,49 \\
3 & $\begin{array}{l}\text { Menjaga } \\
\text { Kesehatan }\end{array}$ & 4,47 & 4,27 \\
\hline & Jumlah & $\mathbf{1 1 , 2 2}$ & $\mathbf{1 1 , 4}$ \\
\hline Rata - Rata & $\mathbf{3 , 7 4}$ & $\mathbf{3 , 8}$ \\
\hline
\end{tabular}

Nilai rata-rata kepentingan dengan angka 3,74 dan nilai rata-rata performance dengan angka 3,8. Kedua nilai ini yang menjadi garis tengah pada diagram Gambar 2.

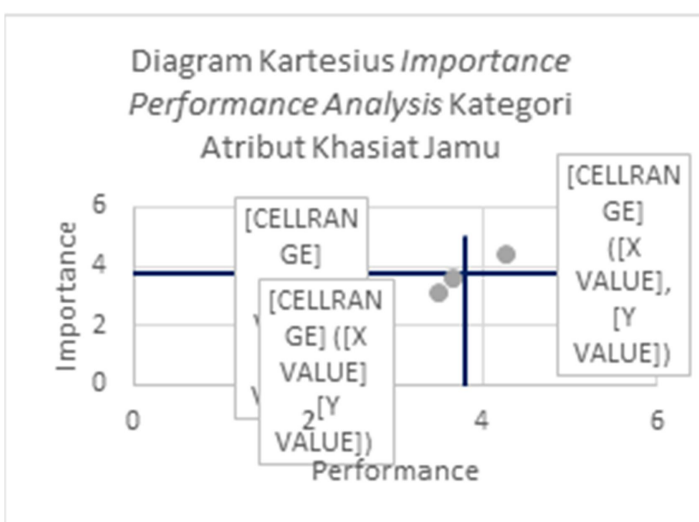

Gambar 2. Diagram Kartesius Atribut Khasiat Jamu

Tabel 3. Kategori Atribut Harga Jamu

\begin{tabular}{|c|c|c|c|}
\hline No & $\begin{array}{c}\text { Kategori } \\
\text { Atribut }\end{array}$ & Importance & Performance \\
\hline 1 & $<5000$ & 3,82 & 4,27 \\
\hline 2 & $\begin{array}{l}5000 \\
10000\end{array}$ & 3,03 & 3,49 \\
\hline 3 & $>10000$ & 1,78 & 2,41 \\
\hline \multicolumn{2}{|c|}{ Jumlah } & 8,63 & 10,17 \\
\hline \multicolumn{2}{|c|}{ Rata-rata } & 2,87 & 3,39 \\
\hline
\end{tabular}

Nilai rata-rata kepentingan dengan angka 2,87 dan nilai rata-rata performance dengan angka 3,39. Kedua nilai ini yang menjadi garis tengah pada diagram Gambar 3.

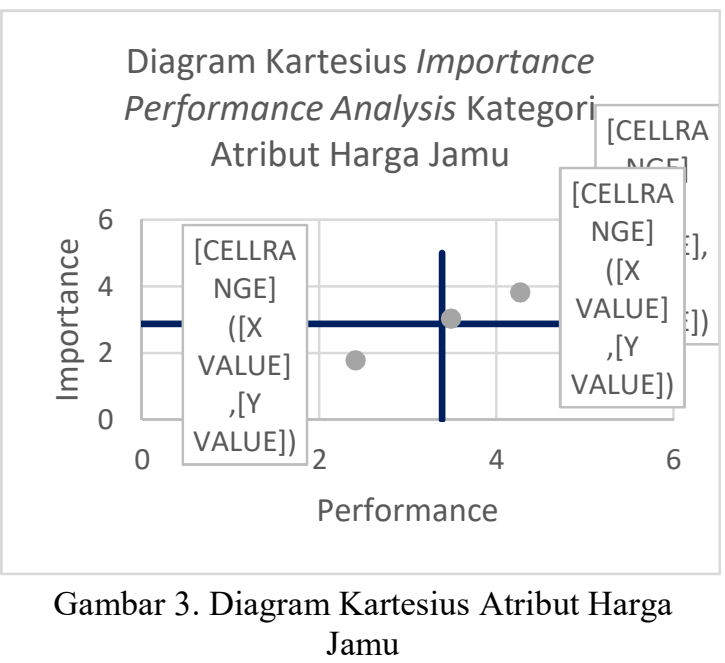

Tabel 4. Kategori Atribut Kandungan Bahan Jamu

\begin{tabular}{|l|l|r|r|}
\hline No & $\begin{array}{l}\text { Kategori } \\
\text { Atribut }\end{array}$ & Importance & Performance \\
\hline 1 & $\begin{array}{l}\text { Tanpa } \\
\text { campuran } \\
\text { bahan } \\
\text { kimia }\end{array}$ & 4,74 & 4,76 \\
\hline 2 & $\begin{array}{l}\text { Dengan } \\
\text { campuran } \\
\text { bahan } \\
\text { kimia }\end{array}$ & 1,15 & 1,19 \\
\hline \multicolumn{2}{|c|}{ Jumlah } & $\mathbf{5 , 8 9}$ & $\mathbf{5 , 9 5}$ \\
\hline \multicolumn{2}{|c|}{ Rata-rata } & $\mathbf{2 , 9 4}$ & $\mathbf{2 , 9 7 5}$ \\
\hline
\end{tabular}

Nilai rata-rata tingkat kepentingan kategori atribut kandungan bahan jamu adalah 2,94 dan nilai rata-rata tingkat kinerja adalah 2,97. Kedua nilai ini yang menjadi garis tengah pada diagram Gambar 4. 


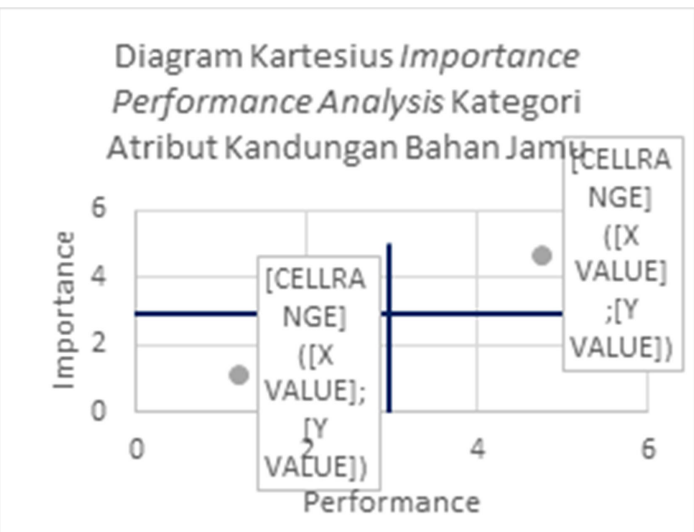

Gambar 4. Diagram Kartesius Atribut Kandungan Bahan Jamu

Tabel 5. Kategori Atribut Cita Rasa Jamu

\begin{tabular}{rrrr}
\hline No & $\begin{array}{c}\text { Kategori } \\
\text { Atribut }\end{array}$ & Importance & Performance \\
\hline 1 & Manis & 2,78 & 2,76 \\
2 & Pahit & 2,82 & 2,84 \\
\hline Jumlah & $\mathbf{5 , 6}$ & $\mathbf{5 , 6}$ \\
\hline Rata-rata & $\mathbf{2 , 8}$ & $\mathbf{2 , 8}$ \\
\hline
\end{tabular}

Nilai rata-rata tingkat kepentingan kategori atribut kandungan bahan jamu adalah dan nilai rata-rata tingkat kinerja adalah sama yaitu 2,8. Kedua nilai ini yang menjadi garis tengah pada diagram Gambar 5.

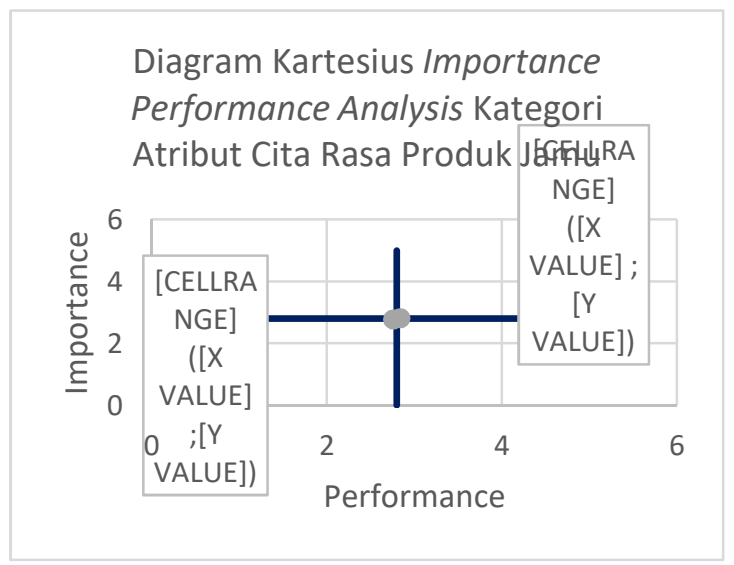

Gambar 5. Diagram Kartesius Atribut Cita Rasa Produk Jamu

Setelah dilakukan pemetaan pada diagram kartesius berdasarkan tingkat kepentingan dan tingkat kinerja hal ini mempermudah untuk melakukan perbaikan setiap kategori dalam suatu atribut bagi responden rumah tangga. Perbaikan kategori atribut tergantung kepada posisi masing-masing dalam kuadran. Kuadran tersebut terbagi menjadi empat seperti berikut:

\section{Kuadran I}

Kuadran I diagram kartesius Importance Performance Analysis (IPA) Dilihat dari atribut dengan masingmasing kategorinya pada Gambar 1-5 tidak terdapat kategori atribut yang termasuk ke dalam kuadran I. Hal ini menunjukkan bahwa tidak ada kategori atribut yang memiliki tingkat kepentingan tinggi bagi responden rumah tangga, dengan tingkat kinerja dibawah rata-rata atau kurang memuaskan.

\section{Kuadran II}

Kuadran II diagram kartesius Importance Performance Analysis (IPA) atau biasa disebut sebagai kuadran "Pertahankan Prestasi". Dilihat dari atribut dengan masing-masing kategorinya pada Gambar 1-5 hampir semua kategori atribut ada didalam di dalam kuadran II. Hal ini menunjukan bahwa tingkat kepentingan suatu kategori atribut tersebut dinilai penting bagi responden rumah tangga. Dengan 
demikian, kategori atribut yang masuk ke dalam kuadran ini harus dipertahankan kinerjanya.

\section{Cairan (Bentuk Penyajian Jamu)}

Berdasarkan Gambar 1, nilai kepentingan kategori atribut cairan bentuk penyajian jamu memiliki nilai kepentingan berada di atas rata-rata kepentingan atribut bentuk penyajian jamu secara keseluruhan. Untuk tingkat kinerja, nilai kinerja berada di atas nilai rata-rata kinerja seluruh atribut sehingga kinerjanya dirasakan baik oleh responden. Nilai untuk masing-masing tingkat kepentingan dan tingkat kinerja kategori atribut cairan sebesar 3,92 dan 4,49 .

2. Menjaga Kesehatan (Khasiat Jamu)

Jamu merupakan salah satu obatobatan tradisional yang digunakan masyarakat Indonesia secara turuntemurun. Jamu sebagai pemelihara kebugaran, kesehatan, dan untuk mengobati berbagai penyakit (Murdijati, dkk. 2018). Hal tersebut sesuai dengan tujuan responden rumah tangga mengonsumsi jamu selama masa Pandemi Covid-19 untuk menajaga kesehatan tubuh. Dilihat dari nilai kepentingan dan kinerja kategori atribut menjaga kesehatan sebesar 4,47 dan 4,27.
3. $<5.000$ dan 5.000-10.000 (Harga Jamu)

Jamu merupakan salah satu obat tradisional. Keputusan mengonsumsi jamu sebagai pengobatan alternatif juga dikarenakan tujuan untuk memperoleh pengobatan yang lebih murah dan efisien (Shimarty, 2008). Hal tersebut sesuai dengan nilai kepentingan dan kinerja kategori atribut harga jamu $<5.000$ dan 5.000-10.000 rupiah yang memiliki nilai di atas nilai rata-rata total atribut harga jamu.

4. Tanpa Campuran Bahan Kimia

Pengobatan tradisional adalah pengobatan yang berasal dari herbal atau tumbuh-tumbuhan. Obat tradisional dipercaya sebagai pengobatan tanpa menggunakan bahan kimia. Pada Gambar 4 kategori atribut tanpa campuran bahan kimia memiliki nilai rata-rata tingkat kepentingan dan kinerja jauh di atas ratarata keseluruhan.

\section{Pahit (Cita Rasa)}

Jamu terkenal dengan rasa pahitnya, karena jamu merupakan ramuan yang berasal dari bahan tanaman obat tanpa pemanis buatan. Pada penelitian ini pelaku pembelian jamu di responden rumah tangga mayoritas adalah ibu rumah tangga, dimana ibu rumah tangga biasanya mengonsumsi jamu untuk 
mendapatkan khasiat tertentu sehingga rasa tidak menjadi masalah utama dalam pembelian jamu. Oleh karena itu, sejalan dengan tingkat kepentingan dan kinerja kategori atribut pahit yang memiliki nilai jauh di atas rata-rata atau sudah sesuai dengan harapan responden.

\section{Kuadran III}

Kuadran III diagram kartesius Importance Performance Analysis (IPA) atau biasa disebut sebagai kuadran "Prioritas Rendah". Hal ini menunjukkan atribut-atribut dengan tingkat kepentingan yang dianggap konsumen kurang penting dan tingkat kinerjanya pun biasa saja. Perbaikan terhadap atribut-atribut yang berada di kuadran ini memiliki prioritas yang rendah karena pengaruhnya terhadap manfaat yang dirasakan konsumen kecil.

1. Bubuk dan Tablet

Berdasarkan Gambar 1, nilai kepentingan kategori atribut bubuk dan tablet bentuk penyajian jamu memiliki nilai kepentingan dibawah rata-rata tingkat kepentingan total atribut artinya kedua kategori atribut ini dirasa kurang penting oleh responden rumah tangga penelitian.
2. Pengobatan Penyakit dan Perawatan Tubuh

Berdasarkan Gambar 2, nilai kepentingan dan kinerja kategori atribut pengobatan penyakit dan perawatan tubuh dalam atribut khasiat jamu keduanya memiliki nilai dibawah nilai rata-rata total. Hal ini dikarenakan mayoritas responden rumah tangga, ketika ada anggota keluarganya yang sakit pengobatan yang mereka cari adalah pengobatan dengan tingkat persentase kesembuhan paling besar dan juga tujuan kepentingan konsumsi jamu yang ingin mereka dapatkan adalah untuk menjaga kesehatan tubuh.

3. $>10.000$

Berdasarkan Gambar 3, kategori atribut harga jamu $>10.000$ rupiah memiliki nilai kepentingan dan kinerja dibawah total rata-rata keseluruhan. Artinya tingkat kepentingan dan kinerja kategori atribut ini dianggap kurang penting dan kurang sesuai harapan responden dikarenakan menurut responden jamu adalah alternatif pengobatan dengan harga yang cenderung murah.

4. Dengan Campuran Bahan Kimia

Kategori atribut jamu dengan campuran bahan kimia dnilai kurang penting oleh responden rumah tangga. 
Dilihat dari Gambar 4, bahwa nilai kepentingan dan kinerja rata-rata kategori atribut campuran bahan kimia memiliki nilai dua kali lebih kecil dari nilai total keseluruhan. Hal ini dianggap kurang penting karena umumnya masyarakat mengonsumsi jamu untuk mendapatkan kandungan alaminya.

5. Manis

Berdasarkan Gambar 5, kategori atribut manis dinilai kurang penting oleh responden rumah tangga karena memiliki nilai kepentingan dan kinerja dibawah nilai rata-rata total. Responden rumah tangga yang melakukan keputusan pembelian jamu pada penelitian ini mayoritas adalah ibu rumah tangga dimana menurut mereka jamu yang berkhasiat adalah jamu yang memiliki cita rasa pahit.

\section{Kuadaran IV}

Kuadran IV diagram kartesius Importance Performance Analysis (IPA) atau biasa disebut sebagai kuadran "Berlebihan". Dilihat dari atribut dengan masing- masing kategorinya pada Gambar 3-6 tidak terdapat kategori atribut yang termasuk ke dalam kuadran IV. Hal ini menunjukkan bahwa tidak ada kategori atribut yang memiliki tingkat kepentingan rendah bagi responden rumah tangga, dengan tingkat kinerja tinggi.

Setelah mendapatkan nilai rata-rata kepentingan dan kinerja atribut yang berasal dari skor-skor setiap kategori, masing-masing nilai tersebut ditotalkan dan kemudian dicari rata-rata untuk atribut jamu yang diteliti. Tujuannya adalah untuk mengetahui posisi setiap atribut di dalam kuadran diagram kartesius sehingga jika terdapat atribut yang perlu diperbaiki hal tersebut akan lebih mudah dipahami bagi pihak stakeholder seperti pada Tabel 6.

Tabel 6. Kategori Atribut Produk Jamu

\begin{tabular}{|c|l|r|r|}
\hline No & $\begin{array}{l}\text { Kategori } \\
\text { Atribut }\end{array}$ & Importance & Performance \\
\hline 1 & $\begin{array}{l}\text { Bentuk } \\
\text { Penyajian } \\
\text { Jamu }\end{array}$ & 2,63 & 3,65 \\
\hline 2 & $\begin{array}{l}\text { Khasiat } \\
\text { Jamu }\end{array}$ & 3,74 & 3,80 \\
\hline 3 & Harga Jamu & 2,87 & 3,39 \\
4 & Kandungan \\
& Bahan Jamu \\
5 & Cita Rasa & 2,94 & 2,97 \\
& Jamu \\
\hline \multicolumn{3}{|l}{ Jumlah } \\
\hline Rata-rata $(\overline{\bar{X}}, \overline{\bar{Y}})$ & $\mathbf{1 4 , 9}$ & 2,80 \\
\hline
\end{tabular}

Berdasarkan Tabel 6 kolom kepentingan (importance) hampir seluruh atribut memiliki nilai 2, sedangkan pada kolom kinerja (performace) nilai yang didapatkan didominasi angka 3. Oleh karena itu, dapat disimpulkan bahwa seluruh atribut memiliki nilai kepentingan di bawah nilai kinerja. Hal tersebut mengindikasikan bahwa kinerja 
yang dihasilkan masing masing atribut berada lebih tinggi dari kepentingan rumah tangga responden.

Nilai rata-rata tingkat kepentingan 5 atribut jamu adalah 2,99 dan nilai ratarata tingkat kinerja adalah 3,32. Kedua nilai ini akan menjadi garis tengah pada diagram kartesius Important Performance Analysis (IPA) sehingga diagram kartersius akan terbagi kedalam empat kuadran. Berikut posisi setiap atribut jamu dalam diagram kartesius Important Performance Analysis (IPA).

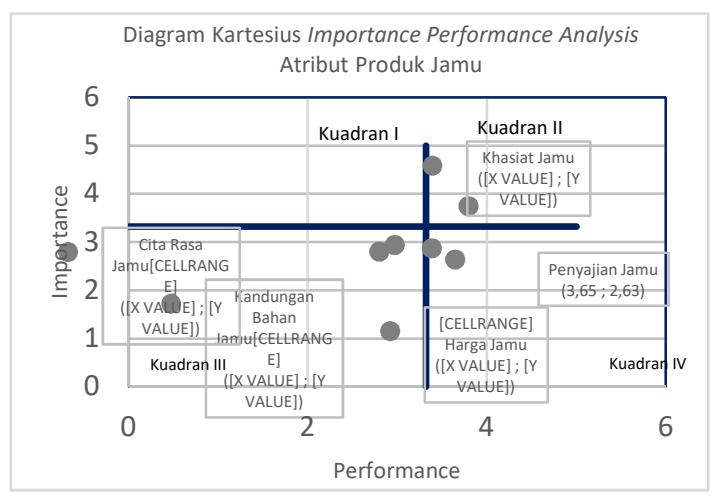

Gambar 6. Diagram Kartesisus Important Performance Analysis Atribut Produk Jamu

Sama seperti pemetaan pada kategori atribut, pemetaan setiap atribut ke dalam diagram kartesius yang berdasarkan tingkat kepentingan dan tingkat kinerja dapat memudahkan pihak terkait untuk melakukan perbaikan atribut yang dianggap sangat penting oleh rumah tangga responden. Perbaikan atribut tergantung pada posisi masing-masing atribut dalam keempat kuadran. Hasil analisis yang didapatkan dengan posisi masing-masing atribut sebagai berikut:

\section{Kuadran I}

Kuadran I menunjukan bahwa tingkat kepentingan dari atribut dianggap sangat penting untuk rumah tangga, namun tingkat kinerjanya masih kurang. Pada lima kategori atribut produk jamu tidak terdapat atribut yang berada pada kuadran I.

\section{Kuadran II}

Kuadran II menunjukan atribut produk jamu pada kuadran ini memiliki tingkat kepentingan dan tingkat kinerja yang sudah memuaskan bagi rumah tangga. Dengan demikian, atribut produk jamu yang berada pada kuadran ini perlu dipertahankan kinerjanya. Atribut produk jamu yang termasuk ke dalam kuadran II adalah atribut khasiat jamu.

1. Atribut Khasiat Jamu

Atribut khasiat jamu dinilai memliki tingkat kepentingan yang tinggi bagi rumah tangga. Menurut mayoritas rumah tangga tujuan melakukan konsumsi jamu untuk mendapatkan khasiat dari jamu itu sendiri. Menurut Herti (2016), responden jamu mengutamakan manfaat dari jamu yaitu tidak adanya efek samping dengan biaya murah, hal ini menunjukan bahwa 
masyarakat masih mempercayai khasiat jamu sebagai obat tradisional.

Walaupun begitu berbeda dalam pemetaan setiap kategori atribut, contoh untuk kategori atribut khasiat jamu menjaga kesehatan tubuh yang berada pada kuadran II dan kategori atribut menyembuhkan penyakit berada pada kuadran III.

\section{Kuadran III}

Kuadran III menunjukan atribut pada kuadran ini memiliki tingkat kepentingan dan kinerja yang rendah sehingga prioritas perbaikannya pun rendah. Atribut jamu yang termasuk dalam kuadran ini adalah:

\section{Cita Rasa Jamu}

Berdasarkan Gambar 7 atribut cita rasa jamu dinilai kurang penting dan kinerjanya rendah bagi rumah tangga. Menurut Angelina (2005), persepsi responden rumah tangga terhadap performance atribut minuman jamu gendong memiliki tingkat kepuasan rendah dikarenakan konsumen menginginkan adanya sensasi rasa lain dalam minuman jamu yang dibeli, bukan hanya rasa jamu yang ditonjolkan.

Walaupun total nilai atribut cita rasa jamu berada pada kuadran III namun berbeda untuk setiap kategorinya contoh kategori atribut pahit berada pada kuadran II.

2. Kandungan Bahan Jamu

Atribut kandungan bahan jamu berada pada kuadran III. Akan tetapi kategori atributnya, kandungan bahan jamu tanpa campuran bahan kimia berada pada kuadran II dan untuk kategori dengan campuran bahan kimia berada pada kuadran III.

\section{Kuadran IV}

Kuadran IV menunjukan atribut yang berada dalam kuadran ini memiliki tingkat kepentingan yang rendah namun kinerjanya tinggi. Atribut produk jamu yang termasuk ke dalam kuadran ini adalah harga jamu dan penyajian jamu.

1. Harga Jamu

Atribut harga jamu memiliki tingkat kepentingan yang rendah dengan kinerja tinggi. Namun berbanding terbalik untuk kategorinya, harga $<5.000$ dan 5.000-10.000 rupiah.

\section{Penyajian Jamu}

Atribut penyajian jamu memiliki tingkat kepentingan dan kinerja yang rendah. Namun berbeda untuk kategorinya contoh bentuk penyajian jamu memiliki tingkat kepentingan dan kinerja yang tinggi. 
Analisis Indeks Kepuasan Konsumen (Customer Satisfaction Index)

Kepuasaan responden rumah tangga terhadap produk jamu pada penelitian ini dianalisis menggunakan Customer Satisfaction Index (CSI). Perhitungan yang dilakukan adalah memperhitungkan nilai rata-rata kepentingan suatu atribut dan kategorinya dan menentukan tingkat kinerja setiap kategori atribut dan nantinya akan memberikan pengaruh terhadap kepuasan total responden rumah tangga.

Hasil analisis ini menggambarkan tingkat kepuasan responden rumah tangga dari tahap sangat tidak puas sampai dengan tahap sangat puas. Hasil perhitungan skor CSI dilihat pada Tabel 6.

Tabel 6. Klasifikasi Kriteria Skor CSI Setiap Atribut

\begin{tabular}{lcc}
\hline \multicolumn{1}{c}{ Atribut } & Skor CSI & Kriteria \\
\hline Bentuk Penyajian & $77 \%$ & Puas \\
Jamu & & \\
Khasiat Jamu & $75 \%$ & Puas \\
Harga Jamu & $71 \%$ & Puas \\
Kandungan Bahan & $81 \%$ & Sangat Puas \\
Jamu & & \\
Cita Rasa Jamu & $56 \%$ & Cukup Puas \\
\hline
\end{tabular}

Hasil penelitian menunjukkan bahwa hasil perhitungan Customer Satisfaction Index (CSI) mayoritas skor CSI atribut termasuk ke dalam krtieria puas dengan rentang skala $66 \%<\mathrm{CSI} \leq$ $80 \%$ yang memiliki arti bahwa tingat kepuasan responden rumah tangga sudah masuk dalam kriteria puas. Hasil skor CSI tersebut menyatakan bahwa mayoritas responden rumah tangga puas terhadap kinerja yang dihasilkan dari kategori atribut masing-masing.

\section{KESIMPULAN DAN SARAN}

\section{Kesimpulan}

1. Hasil importance performance analysis (IPA) pada setiap kategori atribut produk jamu menunjukan bahwa kategori atribut paling penting adalah cairan (atribut bentuk penyajian jamu), menjaga kesehatan (atribut khasiat jamu), $<5.000$ dan 5.00010.000 rupiah (atribut harga jamu), tanpa campuran bahan kimia (atribut kandungan bahan jamu), dan pahit (atribut cita rasa jamu). Masingmasing kategori atribut tersebut merupakan kategori atribut dari produk jamu yang paling disukai dan dianggap penting menurut preferensi rumah tangga di RT 09 dan 10 Kecamatan Sukmajaya.

2. Hasil analisis dari Customer Satisfication Index (CSI) terhadap masing-masing kategori atribut produk jamu memiliki skor yang berbeda. Mayoritas kategori atribut termasuk ke dalam kriteria puas, yaitu atribut 
bentuk penyajian jamu, khasiat jamu, dan harga jamu. Untuk meningkatkan kepuasan kriteria atribut yang kinerjanya masih kurang pihak produsen perlu memperhatikan kategori atribut yang kepentingannya tinggi menurut responden namun kinerjanya masih kurang.

\section{Saran}

1. Pada penelitian selanjutnya, diharapkan menggunakan variabel atribut produk jamu lain, sehingga mampu memberikan penilian dengan pandangan baru untuk pihak produsen jamu.

2. Berdasarkan hasil penelitian, tingkat kepuasan atau indeks kepuasan konsumen untuk atribut cita rasa jamu berada pada kriteria "cukup puas", diharapkan pihak produsen jamu dapat memperbaiki atribut yang bersangkutan agar tingkat kepuasannya dapat meningkat sesuai dengan harapan konsumen jamu.

\section{DAFTAR PUSTAKA}

Badan Pusat Statistik. (2019). Kecamatan Sukmajaya dalam Angka 2019. Jakarta, Badan Pusat Statistik.
Bilson, Simamora. (2002). Metodologi Penelitian. Edisi Kedua. Jakarta. PT Gramedia Pustaka Utama

Bilson, Simamora. (2004). Panduan Riset Perilaku Konsumen. Jakarta. PT Gramedia Pustaka Utama

Herti M, dkk. (2016). Faktor Dalam Pengambilan Keputusan Pembelian Jamu Saintifik. Buletin Penelitian Sistem Kesehatan, Volume 19 No.3 :200 - 210 .

Kotler. (2005). Manajemen Pemasaran, Edisi Milenium, Jilid 1. Jakarta. Prenhallindo

Massnick, F. (1997). The Customer is CEO, How to Measure What Your Customer Wanit and Make Sure They Get It. Newyork. American Management Association

Murdijati G, Eni H, Kamilia L. (2018). JAMU Pusaka Penjaga Kesehatan Bangsa, Asli Indonesia. Yogyakarta. Gadjah Mada University Press, Anggota IKAPI

Peraturan Menteri Kesehatan Nomor 03/Permenkes/Per/I/2020 tentang Saintifikasi Jamu Dalam Penelitian Berbasis Pelayanan Kesehatan.

Shepherd \& Sparks. (1994). Modelling food choice In Measurement of Food Preferences (Eds. D.M.H Thomson \& H.J.H MacFie. London. Blackie Academic Professional.

Sugiyono. (2008). Metode Penelitian Kuantitatif Kualitatif dan $R \& D$. Bandung. ALFABETA 